\title{
The Benefits of Fine Art Integration into Mathematics in Primary School
}

ANJA BREZOVNIK ${ }^{1}$

$\approx$ The main purpose of the article is to research the effects of the integration of fine art content into mathematics on students at the primary school level. The theoretical part consists of the definition of arts integration into education, a discussion of the developmental process of creative mathematical thinking, an explanation of the position of art and mathematics in education today, and a summary of the benefits of arts integration and its positive effects on students. The empirical part reports on the findings of a pedagogical experiment involving two different ways of teaching fifth-grade students: the control group was taught mathematics in a traditional way, while the experimental group was taught with the integration of fine art content into the mathematics lessons. At the end of the teaching periods, four mathematics tests were administered in order to determine the difference in knowledge between the control group and the experimental group. The results of our study confirmed the hypotheses, as we found positive effects of fine art integration into mathematics, with the experimental group achieving higher marks in the mathematics tests than the control group. Our results are consistent with the findings of previous research and studies, which have demonstrated and confirmed that long-term participation in fine art activities offers advantages related to mathematical reasoning, such as intrinsic motivation, visual imagination and reflection on how to generate creative ideas.

Keywords: primary school education, integration, fine art, mathematics, creativity 


\section{Prednosti vključevanja likovne umetnosti v matematiko na razredni stopnji osnovne šole}

ANJA BREZOVNIK

$\propto$ Namen raziskovanja je bil raziskati učinke vključevanja likovne umetnosti v matematiko na učence razredne stopnje osnovne šole. Teoretični del vsebuje definicijo vključevanja likovne umetnosti v pouk raznih šolskih predmetov, proces razvijanja ustvarjalnega matematičnega razmišljanja, pojasnilo današnjega položaja likovne umetnosti in matematike v izobraževanju ter prispevek likovne umetnosti in njene pozitivne učinke na učence. Empirični del obsega pedagoški eksperiment, ki vključuje dva različna načina izvajanja učnega procesa pri pouku matematike učencev petih razredov osnovnih šol. Kontrolna skupna se je učila matematiko na tradicionalen način, v eksperimentalni skupini pa so bili učenci posebej usmerjeni $v$ učenje matematike $z$ vnašanjem vsebin likovne umetnosti. Poučevanju so sledili štirje različni testi znanja, s pomočjo katerih je bila vidna razlika v znanju med učenci, ki so bili izpostavljeni novostim učiteljevega angažiranja $v$ poučevanju, in tistimi, pri katerih omenjenega ni bilo. Rezultati naše raziskave potrjujejo obe zastavljeni hipotezi. Našli smo pozitivne učinke vnašanja likovne umetnosti v matematiko na učence, saj je eksperimentalna skupina pri reševanju matematičnega preizkusa znanja dosegla višje rezultate kot kontrolna skupina. Številne predhodne raziskave so dokazale in potrdile, da dolgoročno udejstvovanje v likovnih dejavnostih učencem daje prednosti, kot sta notranja motivacija in vizualno predstavljanje, navaja pa jih tudi na iskanje ustvarjalnih idej.

Ključne besede: osnovnošolski pouk, integracija, likovna umetnost, matematika, ustvarjalnost 


\section{Introduction}

Giaquinto (2007, p. 1) states that the importance of the integration of visual content into learning mathematics is nothing new, while Gustlin (2012, p. 8) and Catterall (2002) indicate that this way of teaching is a developing field in contemporary education systems. Below we shall see that fine art and mathematics have been connected throughout human history, and that such a connection represents an important area in the development of education today.

Fine art and mathematics are intertwined and have complemented each other from the very beginning (Bahn, 1998, p. VII). The oldest finding is a 70,000-year-old stone from the Blombos cave in Africa, which is an example of abstract art, while at the same time also being a mathematical pattern. Since the beginning of antiquity, we have recorded cases of entertainment mathematics: examples that are only intended to amuse the reader and do not have mathematically useful aims (Berlinghoff \& Gouvea, 2008). The belief that artistic expression contributes to the moral development of society first arises in the Romantic era (Efland, 1990). Both the Eastern and Western worlds connect and integrate the knowledge of artistic and mathematical areas, as is evident in patterned textiles that express traditions, ornaments for religious purposes, the decoration of walls, floors and furniture, etc. An extensive mathematical component can be found in all of these artistic creations, many of which are based on the symmetrical relationships of their patterns (Nasoulas, 200o, p. 364).

Mathematics has been used to create works of art - perspective (BarnesSvarney, 2006), the golden ratio, division, and the illustration of the fourth dimension - while it has also been used for art analysis, such as to reveal relationships between objects or body proportions. Art is useful as a complement to and illustration of mathematical content: diagrams, the golden ratio, trigonometric functions, etc. Revolutionary changes in the fields of art and mathematics have often been closely connected; for example, Renaissance art and the mathematics of that time, new four-dimensional mathematical ideas and Euclidean geometry (The Math and Art and the Art of Math, n.d.).

Throughout history, both artists and mathematicians have been enthusiastic about the same natural phenomena: why flowers have five or eight petals and only rarely six or seven; why snowflakes have a 6-fold symmetric structure; why tigers have stripes and leopards have spots, etc. Mathematicians would say that nature has a mathematical order, while artists would interpret this order as natural beauty with aesthetic value. Both descriptions are possible and reasoned. Children curiously ask the teacher why honeycomb cells always have a hexagonal shape, as they enjoy exploring nature and human creations through 
visual perception, as well as through smelling, touching, tasting, listening to how an object sounds, etc. These experiences lead students to the first mathematical concepts, elements of composition and of patterns containing lines, shapes, textures, sounds and colours. All of this artistic-mathematical beauty reveals itself in the form of shells, spider webs, pinecones and many other creations of nature, all of which teachers can use in class. These objects have been mathematically organised by humans; for example, shapes were mathematically organised in cave paintings in Lascaux, France, and in Altamira, Spain, more than 10,00o years ago (Bahn, 1998; Gardner \& Kleiner, 2014).

In the course of history, society has always included people who have thought in different ways, who have solved problems or undertaken research with the help of previously untried methods. One such person is Escher, who took advantage of his artistic prints to illustrate hyperbolic geometry. Complementing professional mathematics, Escher's circle limit and his patterns demonstrate that art is an efficient transferor that brings mathematics and creative thinking closer to students. His examples demonstrate difficult learning topics, and are therefore an aid to students (Peterson, 2000). Another interesting author is Mandelbrot, who poses the question: "Can a man perceive a clear geometry on the street as beautiful or even as a work of art? When the geometric shape is a fractal, the answer is yes (SIGGRAPH, 1989, p. 21).”

Bill, Mandelbrot, O’Keeffe, Pollock, Vasarely, Warhol and many other artists today create specific artistic works through which teachers successfully teach mathematical content (Ward, 2012).

\section{Theoretical Background}

\section{Defining Arts Integration}

Arts integration is "an approach to teaching in which students construct and demonstrate understanding through an art form. Students engage in a creative process which connects an art form and another subject area and meets evolving objectives in both" (Silverstein \& Layne, 2010).

Fine art is what brings creative thinking into mathematics. The word creativity originates in the Latin word "cero", which means "to do". Lutenist (2012) defines creativity as the ability to look at one thing and see another. As Tucker, President of the National Center on Education and the Economy, said in an interview for the New York Times, the thing we know for sure about creativity is that it typically occurs in people who have graduated from two 
completely different areas. These people use the content of one study as the basic knowledge, and integrate this perspective into another field with a new, expanded view (Friedman, 2010).

\section{The Gradual Acquisition of Artistic-Mathematical Experiences by Students}

Parents have been telling stories about heroes to their children since prehistoric times. After listening, children supplement, define and deepened these stories, expressing the characters personally through their imagination. People have a constant need to find meaning, to link time and space, to fully experience events, bodies, the spiritual, intellect and emotions. Art helps to interlink these elements, many of which would remain unexpressed without it. Since prehistoric times, art has offered a unique source of pleasure and has increased our ability of observation.

From time immemorial, generations have immersed themselves in art, because it reveals the creator's inner self and expresses what is hidden within the personality. However, it is mathematics that is responsible for maintaining the orderliness of what art offers (Gelineau, 2012, p. 3).

Mathematical thinking in children begins with the objects that surround them. They observe these objects, arranging and classifying them according to formal equality or other similarities. Thus children begin to understand the first mathematical concepts. When students see a certain object physically presented, they are able to create an appropriate mental image for it. Its quantity may then also be named and labelled in terms of length, time, mass, etc. (Bristow et al., 2001; Root-Bernstein \& Root-Bernstein, 2013). Simple fine art content in textbooks and notebooks often attracts students to read the accompanying text. A picture can serve as a key, facilitating the interpretation of the text and easing memorisation of the concept. The evaluation of paintings and sculptures in the art class teaches students to read illustrations, drawings and other types of image printed in the teaching material of various school subjects. Students tend to transfer these reading techniques to other forms, such as mathematical graphs. In this way, they are able to read what a graph might represent at first glance. In the process, when students use their imagination to draw what they have heard firstly in their minds and then draw their conceptions on paper, they make a product that they are able to evaluate effectively. Later, when they read the text, it is easier for them to convert words into mental images, which is an important reading skill for mathematical texts as well as other types of text (DaSilva, 2000, p. 40). 
Mathematics can be very creative. Although there is usually only one correct answer, there are many possible ways to find it, one of which can often be through fine art. However, the visual nature of mathematics in schools is often lost in traditional symbols and in instructions with gradual steps. Consequently, students lose opportunities to develop spatial perception and to search for a practically applicable sense of mathematical meaning. Inserting fine art into mathematics classes makes the learning experience more inwardly active and the subject matter more comprehensible. This connection enables different views and approaches to knowledge, deepening and personalising the learning experience. Such a perspective in mathematics opens opportunities for exciting discussions in which students enthusiastically report the different methods they have found leading to the same solution. Students enjoy participating in artistic activities, irrespective of their abilities. The most important and pleasurable thing for them is attending art classes; it does not bother them if they have to solve mathematical problems in parallel or to learn. What they strive to memorise is interesting material (Sylvester, 1998).

\section{The Position of Fine Art in Primary Education Today}

In developed countries, art (fine art, music, dance and drama) is pushed to the edge of formal education for three reasons: art is understood as a leisurely activity, a non-academic activity and an activity that is insignificant for the market economy. It is separated from fundamental education, which is focused on language and mathematics (Burnaford, 2013). DeLeo (2002/2003, p. 2) states that the results of standardised tests are solid evidence of the fact that art does not distract from key academic learning, as is claimed by those who cut school funding for the arts education curriculum. Research shows that art provides additional channels enabling many students to better understand the meaning of various subjects and topics, including mathematics. Eisner (2001, p. 82) says that education in our schools should look more like art, rather than art looking more like our schools. Fine art should be more than something to hang on a billboard; it should be used as a basic framework through which information for all school subjects is transmitted. The art product information (e.g., drawing) should be available to all of the students in a class, not just to the artist or a privileged group of students. While observing Canadian school curricula and students, Pitman (1998) realised that the establishment of elite schools with a rich artistic programme exclusively for students who intend to work in a specific area of the arts throughout their lives does not achieve its real purpose. Every student - not just the elite students - should receive a level of arts education 
that would bring him/her pleasure and increased productivity at work.

Greenspan, an American economist and president of the Federal Reserve of the United States from 1987 to 2006, explained that the emphasis of the US economy is shifting from manufacture-oriented to service-oriented enterprises. If a young person wants to succeed in contemporary jobs, he/she needs an education that develops imagination, ideas, flexibility and a prudent way of thinking. Regular participation in the arts is necessary for the efficient development of the economy, as Riley and Greenspan unanimously continued (Fiske, 1999, p. VI).

In reality, however, the fact is that leaders want to strengthen the economy. For this reason, they first remove the fine art curricula, and only then remove the curricula of other subjects that are not directly connected to the economy (e.g., physical education, music and psychology). The money that was previously assigned to art is then used for additional subjects directly connected to the economy (Gelineau, 2012; Gustlin, 2012; Burnaford, 2013).

\section{The Benefits of Fine Art Integration into Mathematics}

The power of art for the development and well-being of children and adults (as well as plants and animals) has already been widely discovered and confirmed (Dewey, 1934; Gardner, 1973; Dissanayake, 1995; Greene, 1995). The first two noticeable results of fine art integration into teaching are students' increased motivation and curiosity in learning. The main results (creative thinking and the transfer of creativity to other fields) become highly salient within a few years (approx. one to four). Students perceive themselves as successful learners due to this kind of repeated learning experience (Gelineau, 2012).

In order to obtain effective results in fine art, however, the frequent use of fine art lessons alone is not enough; the teacher should develop skills in manifold techniques. Barone (2001), for example, describes an Appalachian teacher of fine art who was aware of this principle and taught his students a range of skills, including traditional knot patterns (macramé), pottery, fibre processing, work on looms, drawing, photography, printing, paper-making, a Malay technique of dyeing fabric (batik), collage, calligraphy, spraying, etc. When students experience sufficient diversity in the arts curriculum and in the types of artistic expression, differences in their interest in specific techniques are revealed, along with gender differences and differences in the quality of artistic performance, as well as differences in the power of the influence of art on individual learners with regard to the aims of teaching content that is not directly related to the arts. 


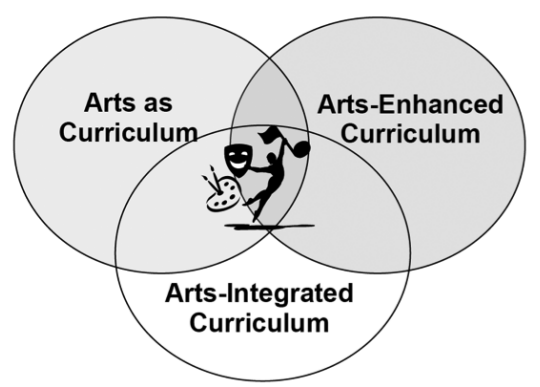

Figure 1. Arts Integration: Three Variations (March 2, 2015). Where to use art in school: in the arts curriculum, in the arts-integrated curriculum and in the arts enhanced curriculum.

Richard Riley, United States Secretary of Education from 1993 to 2001, wrote that the basic challenge of education is to put students on the path of education, on which they will reach both academic success and success in life. Students can easily begin the lifelong journey towards developing their potential and towards cooperation with the environment through learning connected with art. Art teaches students how to learn. It delivers the first step: the desire to learn (Fiske, 1999).

\section{Positive Effects of Fine Art on Mathematics Education}

Research shows that classes that achieve better results in national exams share a cross-curricular integration of all subjects. It seems unfair that only a small proportion of students receive such teaching. Teaching and expecting from students only basic skills and memorising leads away from creativity. Classes that accustom students to creative thinking involve the teacher assisting students to create, research, present and arrive at conclusions. Students need to become familiar with flexible thinking and with looking at things not only as they are but as they could be (Sternberg, 1985).

Davis (2008) writes that, at her school in New York, art is the basis from which a successful curriculum is implemented.

University mathematics lecturer McColm from Florida describes the situation of his students, who each year despair in geometric drawing activities due to their poor spatial ability. This kind of knowledge is the basis of mathematics, but its roots are in artistic content. McColm believes that students would not struggle as much if they had rich previous artistic experience (Gustlin, 2012).

When Gustlin (2012) became a teacher, she noticed that some of the students in the class were a long way from the blackboard. She saw the solution in 
cross-curricular integration, in hands-on activities, in the use of the arts, and in capturing students' imaginations. In order to awaken the students' attention, she began to integrate art into all school subjects on a daily basis. Instead of asking the students to copy from the blackboard into their notebooks, on the first day, she prepared crayons and large-size paper to work on. Thus, a new atmosphere was created in the class. Gustlin proceeded with the regular integration of creativity and arts into teaching and noticed how the students were more intensely involved in the learning process, as well as being pleased to take part in the classes. In 2012, Gustlin asked her own child's teacher why the students did not draw in the mathematics class. The teacher replied that the school did not have enough money to buy art material, simply because mathematics is not a fine art.

Mathematics teacher Guerrero (2004) struggled with similar difficulties when he came to a new primary school. In order to improve classroom discipline, he began to arouse interest, motivation and curiosity by integrating art into teaching. His most important finding was that the students began to learn and gained considerably more knowledge.

A three-year study conducted by Posner, Rothbart, Shees and Kieras $(2008$, p. 6) reaffirms that motivation keeps students focused. Learning by integrating artistic content is usually a stronger motivation than teaching mathematics alone. Students perceive fine art as an absorbing and emotional game. Furthermore, people tend to remember theoretical concepts or knowledge better when it is touched by emotions. Sylvester (1998) believes that emotions lead to attention, and attention leads to learning. Thus, games have an important role in the learning of theoretical concepts, as they motivate and activate several sensory areas at the same time. Students are not as narrowly limited in expression through art language as they are in verbal language. Teachers should therefore encourage students to constantly search for different ways of expression, and to create new forms and structures.

In research involving 2,00o students, Burton, a professor of fine art at Columbia University, also came to the conclusion that subjects like mathematics, science and languages require the complex cognitive and creative skills that are typical of art learning. Compared with students who had not received arts education in the learning process, students who had participated in the arts curriculum at primary school showed significantly greater creativity in their way of thinking, as well as in perception, problem solving and expressing themselves. In addition, they were more confident when taking risks and collaborated better with classmates (Burton et al., 1999).

Since the 1990s, many models have been made with the intention of developing artistic skills in public schools in Canada (Vagianos, 1999). One of them 
is Learning Through the Arts (LTTA), whereby professional educators of artistic content (fine art, music, dance, drama and media) directly taught students in collaboration with their homeroom teachers in order to jointly develop the best possible knowledge required by the curriculum (Elster, 2001). Another LTTA study involved over 6,000 students, parents and educators. According to the authors of the study, the most important finding was that students who had participated in the LTTA primary school programme enriched with art did not become exhausted and give up when learning mathematics and languages, as did the other students who had not received artistically enriched lessons. The second LTTA results showed that their programme had a positive effect on the results of mathematics tests. The third important finding was that intensive effects began to appear after three years of teaching the same students in this way. Therefore, the overall improvement does not become evident immediately, but only gradually. Although one can observe enhanced learning motivation in the first lesson, the transfer of independent creative thinking from artistic creating to, for example, learning about powers, can only be seen after some years. The LTTA's research has had a positive impact on socio-economic changes and on changes in the selection of student activities both within and outside school (Learning Through the Arts, n.d.).

As we can see from the above, a great deal of research demonstrates the positive effects of arts integration into mathematics. However, Hetland et al. (2007), as well as many other teachers around the world, wonder how to explain to school management that it is worth experiencing art in everyday school activities in conjunction with other subjects, and that the visual conceptions of art offer a useful basic understanding and experience of human life.

In order to improve the quality of teaching mathematics, we have undertaken research in ten fifth-grade classes in primary schools (five control classes and five experimental classes), examining the positive effects of the integration of fine art into mathematics. The findings and conclusions of previous research show that today's education neglects creativity and art in education (Gelineau, 2012; Gustlin, 2012; Fiske, 1999; Sternberg, 1985). At the same time, many educators point out that student participation in art encourages more rapid progress in mathematics and critical thinking, as well as in other cognitive skills. We therefore carried out mathematics instruction underpinned with fine art, as a combination of both activates multiple brain areas at the same time. We wanted to facilitate the more efficient processing of information in students by strengthening connections. In this way, the brain is able to combine information and memorise data in multiple ways at the same time. In order to execute the study, we first taught students using the proposed method, after which we tested their knowledge in order to see whether our method encouraged greater academic achievement in mathematics. 


\section{Hypotheses}

- $\quad \mathrm{H} 1$ = The experimental group of students, who receive instruction in mathematics with the integration of fine art content, will achieve better results in mathematics tests than the control group, which does not benefit from the aforementioned approach.

- $\quad \mathrm{H} 2=$ The students in the experimental group who perform better in fine art will achieve better results in mathematics tests while learning mathematics with integrated fine art content than students who perform better in fine art in the control group.

\section{Research Method}

We used the descriptive and the causal-experimental method and performed a non-probability pedagogical experiment within two comparison groups (the experimental group and the control group).

\section{Sample}

The target population of the survey was fifth-grade students of primary schools in the Republic of Slovenia. A total of 210 students participated: 105 in the control group and 105 in the experimental group. The survey was conducted in ten randomly selected classes from different regions in the country. The students were taught by their homeroom teachers, who had many years of teaching experience. Fifth-grade students were selected for the research because the mathematical subject matter in this grade is no longer as playful as in the lower grades and is less frequently presented visually. Consequently, we expected these students to experience less artistic content in mathematics than those in previous grades.

Table 1. Structure of the Sample by Group

\begin{tabular}{lll}
\hline GROUP & $\mathbf{f}$ & $\%$ \\
\hline Control & 105 & 50 \\
Experimental & 105 & 50 \\
Total & 210 & 100 \\
\hline
\end{tabular}




\section{Measurement Instruments}

We conducted four mathematics tests.

- The sensitivity of the tests was checked by Ferguson's coefficient delta.

- The objectivity of execution was ensured by clear and unambiguous instructions, questions and problems. The students of both groups completed the same exercises and had an equal amount of time at their disposal.

- The reliability of the tests was verified using Cronbach's coefficient alpha.

- The validity of the content was verified by three experts, and the construct validity was determined by a factor analysis.

\section{Research Method and Data Collection}

Prior to the experiment, we compared the control group and the experimental group based on the students' marks in fine art and mathematics programmes from the previous school year.

During the pedagogical experiment, the teachers of the control group and the experimental group simultaneously taught students four new mathematical learning topics: equations, inequations, powers and perimeter. The teachers of the control group taught lessons in the traditional way (without arts integration), while the teachers of the experimental group taught in a new way, with integration of fine art content into mathematics: artistic balance was integrated into equations, imbalance into inequations, rhythm into powers and architectural space into perimeter. We prepared detailed lesson plans for the teachers and instructed them in the new teaching strategies before they started teaching the students. The students sat a mathematics test after each of the completed learning topics, thus sitting a total of four tests. The tests were prepared in advance, and structured using Gagne's taxonomy. The experiment was carried out during regular school lessons.

\section{Results}

\section{Analysis Prior to the Experiment}

In order to find relationships between student knowledge in the control group and the experimental group, we used the final marks of fine art and mathematics programmes from the academic year directly prior to realising the experiment. 
Table 2. The average scores of the control and experimental groups in the year prior to the experiment

\begin{tabular}{llrrr}
\hline & Group & $\boldsymbol{N}$ & $\boldsymbol{M}$ & SD \\
\hline \multirow{2}{*}{ Previous year fine art marks } & Control & 105 & 4.410 & 0.781 \\
& Experimental & 105 & 4.610 & 0.563 \\
\hline \multirow{2}{*}{ Previous year mathematics marks } & Control & 105 & 3.857 & 1.042 \\
& Experimental & 105 & 3.971 & 0.995 \\
\hline
\end{tabular}

A study of group statistics shows that the average scores of the control and experimental groups in the year prior to the experiment are different in fine art but similar in mathematics. The experimental group achieved higher scores $(M=4.410)$ in fine art than the control group $(M=4.410)$. Both groups scored higher marks in fine art than in mathematics.

Table 3. T-test for Independent Samples

\begin{tabular}{|c|c|c|c|c|c|c|}
\hline & Group & $\mathrm{F}$ & $p$ & $t$ & $d f$ & $p$ \\
\hline Last year fine art marks & $\begin{array}{l}\text { Control } \\
\text { Experimental }\end{array}$ & 11.68 & 0.001 & -2.129 & 189.179 & 0.001 \\
\hline Last year mathematics marks & $\begin{array}{l}\text { Control } \\
\text { Experimental }\end{array}$ & 0.433 & 0.511 & -0.813 & 208 & 0.511 \\
\hline
\end{tabular}

T-test for independent Samples shows that there were statistically important differences between the control group and the experimental group in the previous year's fine art marks $(F=-2,129, p=0.001)$. Comparing the control group and the experimental group, the values of the previous year's mathematics marks were not statistically important.

\section{Pedagogical Experiment Results}

We marked the students' mathematics tests with scores from zero to twelve because we wanted to obtain more precise results than we would with marks expressed from one to five. 
Table 4. The Criterion

\begin{tabular}{lc}
\hline Points & Mark \\
\hline $0-6.49$ & 1 \\
$6.50-8.49$ & 2 \\
$8.50-10.49$ & 3 \\
$10.50-11.49$ & 4 \\
$11.50-12$ & 5 \\
\hline
\end{tabular}

\section{Hypothesis 1}

We confirm the first hypothesis.

Table 5. Descriptive Statistics

\begin{tabular}{llrrr}
\hline Mathematics test & Group & $\boldsymbol{N}$ & $\boldsymbol{M}$ & SD \\
\hline \multirow{2}{*}{ Equations } & Control & 105 & 6.9429 & 3.21902 \\
& Experimental & 105 & 9.4571 & 2.03823 \\
\hline \multirow{2}{*}{ Inequations } & Control & 105 & 6.7333 & 2.68996 \\
& Experimental & 105 & 9.3238 & 2.34314 \\
\hline \multirow{2}{*}{ Powers } & Control & 105 & 6.6476 & 2.69251 \\
& Experimental & 105 & 9.3333 & 2.51024 \\
\hline \multirow{2}{*}{ Perimeter } & Control & 105 & 8.4857 & 2.37420 \\
& Experimental & 105 & 9.9429 & 2.08856 \\
\hline
\end{tabular}

Descriptive statistics in all four mathematics tests in the control group and the experimental group show: $N=105$ in the control group and the experimental group in all four mathematics tests. The mean for the condition Equations in the control group is 6.94 and in the experimental group is 9.46. The experimental group achieved better results in the mathematics tests than the control group. The experimental group also achieved better results in the other three mathematics tests. SD for all of the tests is between 2.04 and 3.22.

Table 6. T-test for Independent Samples

\begin{tabular}{lrrr}
\hline Mathematics test & $\boldsymbol{t}$ & $\boldsymbol{d f}$ & $\boldsymbol{p}$ \\
\hline Equations & -6.762 & 175.844 & 0.000 \\
Inequations & -7.441 & 208 & 0.000 \\
Powers & -7.476 & 208 & 0.000 \\
Perimeter & -4.722 & 208 & 0.000 \\
\hline
\end{tabular}


Table 6 shows a comparison of whether the control group and the experimental group have different average values. We can see that the means of all four mathematics tests are significantly different, as $p<0.05$. Looking at the Descriptive Statistics table, it is evident that those students who attended the lessons taught in the traditional way achieved fewer points in the mathematics tests than those who experienced the new way of learning with the integration of fine art content into mathematics.

Table 7. Levene's Test for Equality of Variances

\begin{tabular}{lrrrr}
\hline Mathematics test & $\mathbf{F}$ & $\boldsymbol{d f 1}$ & $\boldsymbol{d f 2}$ & $\boldsymbol{p}$ \\
\hline Equations & 21.607 & 1 & 208 & 0.000 \\
Inequations & 0.319 & 1 & 208 & 0.573 \\
Powers & 0.139 & 1 & 208 & 0.709 \\
Perimeter & 2.740 & 1 & 208 & 0.099 \\
\hline
\end{tabular}

Table 8. Multivariate Tests: The Effect of Fine Art

\begin{tabular}{|c|c|c|c|c|c|}
\hline & Value & $\mathrm{F}$ & $d f_{\text {(Hypothesis) }}$ & $d f_{\text {(Error) }}$ & $p$ \\
\hline Wilks' Lambda & 0.657 & 26.703 & 4.000 & 205.000 & 0.000 \\
\hline
\end{tabular}

The multivariate test shows that we obtained a statistically significant result for the first hypothesis. This means that the null hypothesis is discarded. The groups of students were statistically significantly different in relation to their academic achievements, which supports our first hypothesis. The null hypothesis of the multivariate test Wilks' Lambda shows that there is no statistically important difference between the groups.

The multivariate test shows that we obtained a statistically significant difference in academic achievements, F (4.205) = 26.70, $p<0.0005$; Wilk's $\Lambda$ $=0.657$.

Table 9. Tests of Between-Subject Effects

\begin{tabular}{llrrr}
\hline Source & & $\boldsymbol{F}$ & $\boldsymbol{d f}$ & $\boldsymbol{p}$ \\
\hline Co-Ex & Equations & 45.725 & 1 & 0.000 \\
& Inequations & 55.367 & 1 & 0.000 \\
& Powers & 55.891 & 1 & 0.000 \\
& Perimeter & 22.297 & 1 & 0.000 \\
\hline
\end{tabular}


From Table 9 we can see that the integration of fine art into mathematics has a statistically significant effect on all of the research topics: Equations ( $F$ (1. $208)=45.73 ; p<0.0005)$, Inequations $(\mathrm{F}(1.208)=55.37 ; p<0.0005)$, Powers $(\mathrm{F}$ $(1.208)=55.89 ; p<0.0005)$, Perimeter $(\mathrm{F}(1.208)=22.30 ; p<0.0005)$.

We found the greatest difference in the fine art effect on mathematics between the control group and the experimental group in the topic Powers, and the smallest difference in Perimeter. The latter is a topic that is already visual by nature, which could explain the smaller difference in the mathematics test results.

\section{Hypothesis 2}

We confirm the second hypothesis.

Students who had achieved a mark of 5 in the previous year's fine art programme were considered to be successful students. In the experimental group, such students achieved better results in all four mathematics tests in comparison to those in the control group. The biggest difference was found in the topic Powers, and the smallest in Perimeter.

Table 10. Descriptive Statistics ${ }^{a}$

\begin{tabular}{llrrr}
\hline Control or Experimental Group & $\boldsymbol{M}$ & $\boldsymbol{S D}$ & $\boldsymbol{N}$ \\
\hline Equations & Control & 7.8814 & 2.88925 & 59 \\
& Experimental & 9.7941 & 1.88124 & 68 \\
& Total & 8.9055 & 2.57717 & 127 \\
\hline Inequations & Control & 7.2203 & 1.95702 & 59 \\
& Experimental & 9.7059 & 2.35669 & 68 \\
& Total & 8.5512 & 2.50304 & 127 \\
\hline Powers & Control & 6.9153 & 2.40895 & 59 \\
& Experimental & 9.6765 & 2.23568 & 68 \\
& Total & 8.3937 & 2.69084 & 127 \\
\hline Perimeter & Control & 8.7627 & 2.51437 & 59 \\
& Experimental & 10.1029 & 2.17955 & 68 \\
& Total & 9.4803 & 2.42621 & 127 \\
\hline
\end{tabular}

a. Previous year's mark in fine art $=5.00$ 
Descriptive statistics in the mathematics tests in the control group and the experimental group for students with a fine art grade of 5 show: $N=59$ in the control group, $N=68$ in the experimental group in all four mathematics tests. The mean for Equations in the control group is 7.88 and in the experimental group is 9.79. The experimental group therefore achieved better results in mathematics tests than the control group. The experimental group also achieved better results in the other three mathematics tests. $S D$ for all of the tests is between 1.88 and 2.89 .

Table 11. Multivariate Tests

\begin{tabular}{|c|c|c|c|c|c|}
\hline & Value & $\mathrm{F}$ & $d f_{\text {(Hypothesis) }}$ & $d f_{\text {(Error) }}$ & $p$ \\
\hline Wilks' Lamba & 0.654 & 16.153 & 4.000 & 122.000 & 0.000 \\
\hline
\end{tabular}

The multivariate test shows that we obtained statistically significant result for the second hypothesis, which means that the null hypothesis is discarded. The groups of students were statistically significantly different in terms of academic achievements, which supports our second hypothesis. The null hypothesis of the multivariate test Wilk's Lambda shows that there is no difference between the groups.

There was a statistically significant difference in the effect of fine art: $\mathrm{F}$ (4. 122) $=16.15, p<0.0005, V=0.346$.

Table 12. Tests of Between-Subject Effects

\begin{tabular}{llrrr}
\hline Source & & $F$ & $d f$ & $p$ \\
\hline Co-Ex & Equations & 20.030 & 1 & 0.000 \\
& Inequations & 41.052 & 1 & 0.000 \\
& Powers & 44.838 & 1 & 0.000 \\
& Perimeter & 10.355 & 1 & 0.001 \\
\hline
\end{tabular}

Table 12 shows that the integration of fine art into mathematics has a statistically significant effect in all research topics on students with a fine art mark of 5: Equations $(\mathrm{F}(1.125)=20.03 ; p<0.005)$, Inequations $(\mathrm{F}(1.125)=$ 41.05; $p<0.005)$, Powers $(\mathrm{F}(1.125)=44.84 ; p<0.005)$, Perimeter $(\mathrm{F}(1.125)=$ 10.36; $p<0.005)$. 


\section{Art Results of Students in the Experimental Group}

The experimental group created different fine art products to achieve fine art effects while learning mathematics.

Example 1: When the students in the experimental group were learning about equations, they painted a view out of a fairy-tale window. The window had two parts - the left and the right casement - which divided the paper into two equal parts. This helped the students to paint balance. The left and the right side of the casement included the same painting, but with one difference, which represented the unknown $(\mathrm{x})$ in equations.

- As the first student example below shows, there are four planets in the space on the left casement. On the one on the right, we see the same view, but a lunar eclipse occurs and hides some planets. We can see that only two planets are left. How many of them are hidden under the moon? The answer is:

4 planets $=2$ planets $+x$

4 planets -2 planets $=x$

$\mathrm{x}=2$

The students glued the $\mathrm{x}$ (the moon) onto the painting, so that if it was lifted from the bottom side, the equation written under the moon was visible. In this way, the students observed their paintings (equations), tried to solve them, and at the end checked the answer under the glued $\mathrm{x}$.

- The second student example shows shells on a beach, some of which are hidden by a ball. Writing the equation gives the answer to the question "How many shells are under the ball?" To check the answer, the ball is lifted up and the answer under it is revealed.
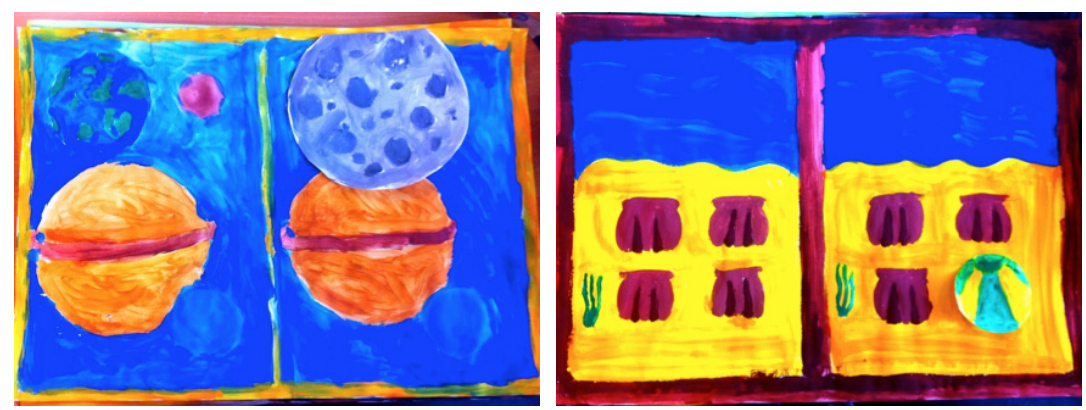

Pictures 2 and 3. Paintings by fifth-grade students from Slovenia, 2014/2015 school year. 
Example 2: When they were learning about powers, the students made up a story about "small on smallest" and drew it with crayons.

- $\quad$ The first student example below shows a story about two spaces. Each space has two planets. Each planet has two continents with two countries. Each country has two communities with two houses. This story represents the power $2^{6}$.

- The second student example below shows a story about a farm. There are three sheep pens. Each has three sheep. Each sheep has three lambs. This story represents the power $3^{3}$.
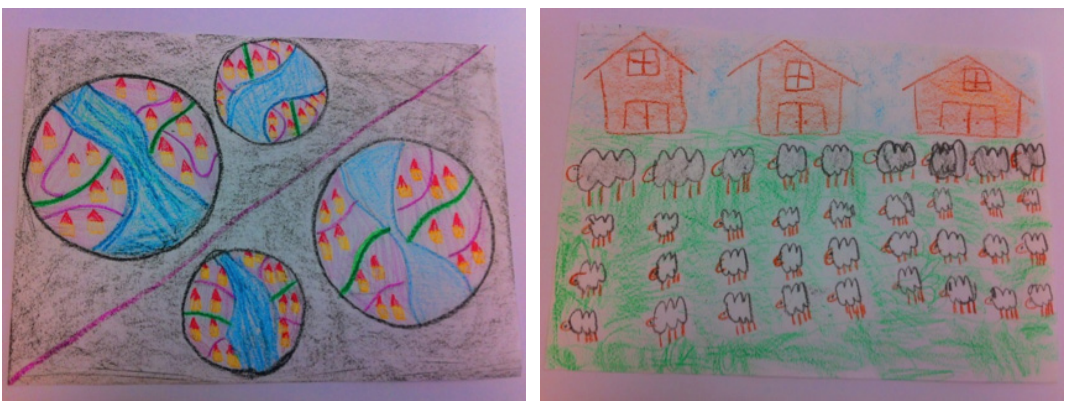

Pictures 4 and 5. Paintings by fifth-grade students from Slovenia, 2014/2015 school year.

\section{Conclusion and Final Thoughts}

We can confirm that our method of teaching mathematics with fine art integration enabled greater academic achievements in the experimental group than in the control group, where the students had not benefitted from the above approach. This was established with the first hypothesis. The experimental group achieved better results in all four tests. We also confirmed the second hypothesis. Our research shows that, after learning mathematics integrated with fine art content, the students of the experimental group who were successful in fine art achieved better results in all four tests than those of the control group.

Our research reveals important positive effects immediately after teaching just a few mathematics topics. Other research shows that even more significant results occur 3-5 years after arts integration into teaching the same students (Chapman, 1998; Gelineau, 2012; Learning Through the Arts, n.d.). In order to determine the long-term effects, it would be interesting to continue our method of teaching, and to examine the students and verify their knowledge and their way of thinking again after four years. 
The basic purpose of the connection between these two subjects for students is to make education effective and absorbing. Primary school mathematics teaches fundamental knowledge that an individual uses daily throughout his/her life. Students who feel the beauty, playfulness, challenge and utility of mathematics from the early school grades onwards would be more prepared to work harder on mathematics in the later grades, when the content becomes less visibly imaginable and more symbolic. Students will also become more inclined to become involved in related fields, such as architecture, physics, engineering, economics, computer science and other fields that are important today. Students need both knowledge and creativity to satisfy the comprehensive needs of today's rapidly changing society.

"If a child can't learn the way we teach, maybe we should teach the way they learn" (Ignacio Estrada).

\section{Literature}

Arts Integration Three Variations (n.d.). Retrieved 02.03.2015 from http://www.middleweb.com/wpcontent/uploads/2013/03/arts-integration-three-variations.jpg

Bahn, P. G. (1998). The Cambridge Illustrated History of Prehistoric Art. Cambridge: Cambridge University Press.

Barnes - Svarney, P. (2006). The Handy Math Answer Book. Detroit: Visible Ink Press.

Barone, T. (2001). Touching Eternity: The Enduring Outcomes of Teaching. New York: Teachers College Press.

Berlinghoff, W. P., \& Gouvea, F. Q. (2008). Matematika skozi stoletja. Ljubljana: Modrijan.

Bristow, J., Cowley, P., \& Daines, B. (2001). Spomin in učenje. Ljubljana: Educy.

Burnaford, G. E. (2013). Renaissance in the classroom: Arts integration and meaningful learning.

Mahwah, N.J: L. Erlbaum.

Burton, J., Horowitz, R., \& Abeles, H. (1999). Learning in and through the arts: Curriculum implications. In Champions of change: The impact of the arts on learning (pp. 35-46). Columbia:

Columbia University.

Catterall, J. S. (2002). The arts and the transfer of learning. In R. J. Deasy (Ed.), Critical links:

Learning in the arts and student academic and social development (pp. 151-157). Washington: Arts

Education Partnership.

Chapman, R. (1998). The Arts Improve Student Performance. Education Digest, 63(8), 58-60.

DaSilva, K. E. (2000). Art in Your Curriculum "From Words to Images". Teaching Pre K 8, 31, 40-43.

Davis, J. H. (2008). Why our schools need the arts. New York, NY: Teachers College Press.

Dewey, J. (1934). Art as experience. New York: Putnam.

Dissanayake, E. (1995). Homo aestheticus. Seattle: University of Washington Press.

Efland, A. (1990). A history of art education: Intellectual and social currents in teaching the visual arts. 
New York: Teachers College Press.

Eisner, E. (2001). Should we create new aims for art education? Art Education, 54(5), 6-10.

Elster, A. (2001). Learning Through the Arts ${ }^{\mathrm{TM}}$ : Program Goals, Features and Pilot Results.

International Journal of Education and the Arts, 2(7).

Fiske. E. B. (1999). Champions of Change: The Impact of the Arts on Learning. Retrieved 11.05.2014 from http://eric.ed.gov/?id=ED435581

Friedman, T. (2010). Newspaper interview, Tucker Marc. New York Times (OpEd), 4 August 2010.

Gardner, H. (1973). The arts and human development: A psychological study of the artistic process.

New York: Wiley \& Sons.

Gardner, H., \& Kleiner, F. S. (2014). Gardner's art through the ages: The Western perspective. Boston,

MA: Wadsworth/Cengage Learning.

Gelineau, R. P. (2012). Integrating the arts across the elementary school curriculum. Belmont CA:

Wadsworth.

Giaquinto, M. (2007). Visual Thinking in Mathematics; An Epistemological Study. Oxford: Oxford

University Press.

Greene, M. (1995). Releasing the Imagination: Essays on Education, the Arts, and Social Change. New

York: Teachers College Press.

Guerrero, J. S. (2004). Learning Math through Visual Art and Hands on Projects. Spring Valley: Xlibris Corporation.

Gustlin, D. Z. (2012). Why Can't We Paint in Math Class? Integrating Art into the Core Curriculum: masterclass work. Gainesville: [Gustlin, D. Z.].

Hetland, L., Winner, E., Veenema, S., \& Sheridan, K. (2007). Studio thinking: The real benefits of visual arts education. New York, NY: Teachers College Press.

Learning Through the Arts, Royal Conservatory of Music - Learning (n.d.). Retrieved 30.04.2015 from http://learning.rcmusic.ca/ltta

Peterson, I. (23 December 2000). Visions of Infinity Tiling a hyperbolic floor inspires both mathematics and art. Science News Washington, 158, 408-410.

Pitman, W. (1998). Learning the arts in an age of uncertainty. Toronto: Arts Education Council of Ontario.

Posner, M., Rothbart, M. K., Sheese B. E., \& Kieras, J. (2008). How Arts Training Influences Cognition. Learning, Arts and the Brain. The Dana Consortium Report on Arts and Cognition. New York: Dana Press.

Root - Bernstein, M. M., \& Root - Bernstein, R. S. (2013). Sparks of genius: The thirteen thinking tools of the world's most creative people. Boston, Mass: Houghton Mifflin Harcourt.

SIGGRAPH. (1989). Computer art in context: SIGGRAPH'89 art show catalog. Oxford: Pergamon Press.

Silverstein L. B., \& Layne S. (2010). Defining Arts Integration. Retrieved 15.09.2014 from http://www. kenndy-center.org/education/partners/defimimg_arts_integration.pdf Sternberg, R. J. (1985). Beyond IQ: A triarchic theory of human intelligence. Cambridge 
[Cambridgeshire]: Cambridge University Press.

Sylvester, R. (1998). Art for the brain's sake. Educational Leadership, 56(3), 31-35.

Vagianos, A. (1999). Professional development and training for teachers and artists. A preliminary proposal for a Laidlaw Foundation arts education program. Unpublished manuscript. Laidlaw Foundation, 365 Bloor Street East, Suite 2000, Toronto, ON M4W $3 \mathrm{~L}_{4}$.

Ward, R. A. (2012). Math Art Fun: Activities for Discovering Mathematical Magic in Modern Art. Houston: Bright Sky Press.

\section{Biographical note}

ANJA BREzovNIK is finishing the fourth year of Ph.D. on art and mathematics at University of Ljubljana, Slovenia. She has pedagogical experiences on teaching in primary school education and kindergarten at Slovenian national curriculum, English national curriculum, US national curriculum and at International Baccalaureate World School. Her focus is on integration of arts into daily primary school education. She has participated in international projects, conferences and carried out workshops (DMRS, DI4R, CCUSA, Comenius, eTwinning, Hawaiian International Conference on Education, etc). 